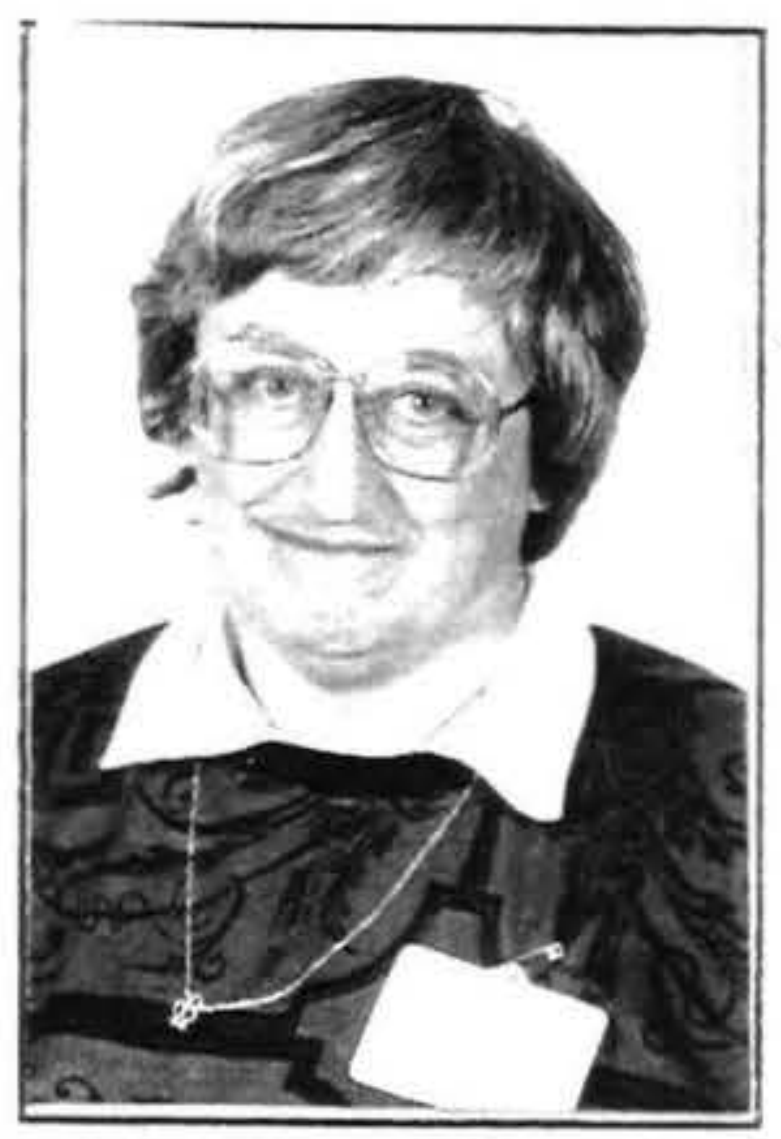

\title{
PARTICIPATION IN PAID AND UNPAID WORK: RHETORIC, POLICY AND REALITIES FOR WOMEN IN THE 'YEAR OF THE FAMILY'
}

\author{
Prue Hyman \\ Victoria University of Wellington
}

\begin{abstract}
The rhetoric of the year of the family is celebrative, encouraging, and cognisant of the variety of family forms: 'it is a year for us to celebrate families in New Zealand and it is also a time to focus on ways we can help families to carry out their very important task of raising their children'. It hints at the desirability of equality within the family, and of community/state support, with the comment that one result expected to be achieved is 'Formal recognition by the nation of ongoing support for the family as the essential unit in which each memberis important and has recognised status'. It even recognises, with the police campaign 'Not Just a Domestic', the problem of domestic violence, although not that it is overwhelmingly male violence.
\end{abstract}

Policies towards the family are dominated by the handsoff, individualistic, self reliance attitudes underlying govemment philosophy, with inadequate support for families with young and other dependents. Such individual freedom is, however, in practice substantially qualified. Sole parent families continue to be stigmatised, with misuse of research on the situation of children in one and two partner households, and myopia about the reasons why many women have to leave relationships. Lesbian and gay households receive even worse treatment, with custody difficulties and denial of adoption and fertility rights implying a lack of acknowledgement of any family status. Policy support for gender equity and equal sharing of paid and unpaid work in the market and household, which would indicate a move towards genuine choice for all within families, is notable by its absence.

This paper attempts to flesh out some of these contradictions and the realities for women caught in them.

\section{Diversity of family forms/households/ways of living}

Appreciation (worship?) of the family is confined in govemment philosophy to the nuclear, two parents and children, family. Even in the rhetoric, the theoretical appreciation of diversity extends only to ethnic differences and extended families. Sole parent families are ignored or criticised as inferior, and marriage and heterosexuality seen as the only desirable site for the raising of children. The view of feminist anthropologists such as Julie Marcus that the nuclear families may be far from a natural functional form (Smith, 1994) is given no weight. While the official material produced for the Year of the Family acknowledges that the nuclear family is declining, much policy emphasis is on reversing this trend rather than making sole parenthood, still overwhelmingly sole motherhood, a less difficult option. The Year of the Family's March/April 1994 newsletter reports the increase between 1986 and 1991 from $21 \%$ to $26 \%$ in sole parent families, with $20 \%$ of all children, $44 \%$ of Maori children and $32 \%$ of Pacific Island families living in such families. It further states that sole parents are usually disadvantaged in terms of employment, income, education and housing tenure.

The vast majority of people bringing children up on their own are women, although sole fathers increased from $13 \%$ to $16 \%$ of the total between 1986 and 1991 (New Zealand Department of Social Welfare, 1993). Sole fathers receive attention and an odd mixture of curiosity, admiration, and stigma beyond their numbers. They are more likely to be in paid work than sole mothers, due partly to societal expectations and their greater earning power. Thus only $6.3 \%$ of domestic purposes beneficiaries in 1987 were men, although the rate of sole fatherhood was double this. Labour force participation for sole mothers is lower than that of women in two parent families. For all sole parents, the full time employment rate declined from $27 \%$ in 1986 to $21 \%$ in 1991 , with a dramatic fall for sole fathers between 1976 and 1991 from $81 \%$ to $44 \%$. The difficult employment situation, high effective marginal tax rates and child care difficulties are among the factors responsible for this. In Sweden by contrast, almost $90 \%$ of sole parents are in the labour force, with better support policies.

However the thrust of recent policy has been not to improve their financial position, but instead to cut domestic purposes benefit and raise rents in Housing New 
Zealand dwellings. The few sole parents under eighteen have been denied the Domestic Purposes Benefit (DPB) and it is intended that beneficiaries should be 'work ready' and if possible return to employment when the youngest child reaches seven. This has been deferred while the unemployment situation is adverse, but special retraining schemes are being piloted. Most women on the domestic purposes benefit wish to reenter the paid workforce once their children are old enough, which is not surprising given its fairly modest level, the stigmatising of beneficiaries, and the desire for independence. With the 1991 benefit cuts, and the criticism and invasion of privacy with respect to relationships, it is not surprising that the number of benefits in force have levelled off (Preston, 1993). This result could be claimed as a success of the cuts, saving both in quantity and rates. However, such a conclusion ignores the costs falling on voluntary agencies, on those affected, especially women and children, and possible indirect costs on government. Nor do the trends support the contention that high replacement rates are a major reason for this group not being in paid work, when only $17 \%$ of those moving off the benefit in the year to March 1993 were placed in work, as against $43 \%$ changing their marital status, $12 \%$ transferring to another benefit, and $11 \%$ having children who left their care or reached the maximum age (ibid).

The hardship caused to those remaining on benefits has been assessed in a number of studies. Reviewing these results and the demands on food banks and social service agencies, as well as their own survey of 23 Christchurch recipients of the domestic purposes benefit, Dann and Du Plessis argued that: "The overall picture gained from the study is of normal people in abnormal circumstances. They utilise all sorts of strategies to survive... The analysis of how income is allocated in these households reveals the extent to which those interviewed are going without essentials in order to survive" (Dann and du Plessis, 1991: 66).

The feminisation of poverty is largely a phenomenon of hardship among sole parents, in New Zealand as in Australia, Great Britain and the United States. Poverty incidence has risen among sole parents, low income familes and their children relative to other groups, partly due to welcome improvements in superannuation and resulting reduced hardship among the elderly (Stephens, 1987).

Policies aimed at producing economic incentives to reenter the labour force frequently appear more realistically to provide severe disincentives or punishments for resisting. Nevertheless, such economic incentives are supplemented by ideological arguments, supported by selective research results. Thus renewed emphasis is put on the desirability of having full time mothering in a child's early years to reinforce labour force withdrawal for partnered (but not unpartnered) women. Simultaneously the ideology of the nuclear family is reasserted, together with the desirability of children being brought up by both parents (Mannion, 1993: 21). This ignores the gender specific reasons for women leaving heterosexual relationships, with increas- ing demands on women's refuges and applications for non-molestation orders attesting to the high incidence of violence within marriage, perpetrated largely by men. Research results which show that children of sole parents have some social and economic disadvantages on average compared to two parent families (Martin, 1994) are misused for sole parent bashing. A fairer comparison would be with outcomes for children in two parent disfunctional families, including those where male violence is a problem. Leaving such relationships is likely to give improved outcomes for women and their children. Mannion's arguments were based on research findings from the Christchurch Child Development Study. Earlier publications from this study on maternal workforce participation have been the subject of criticism along feminist deconstruction lines, arguing that the methodology and reading of the results is inevitably and in fact influenced by the subject position of the researchers, while being presented as unambiguously objective (Du Plessiz Novitz, 1990).

Nevertheless, orthodox economics, policy based on it, and most of its feminist critics share the assumption that heterosexuality, marriage, and raising children within it, constitutes the family form which is the norm or even the universal experience of women. There is a failure to examine the social construction of what has been made to be an inevitable reality for many women. The new home economics extends economics to the private world of the household, choice of marriage partners, quantity and 'quality' of children, allocation of time, but in doing so, treats all women as wives and mothers and through its focus on rational choice, implies a gender power symmetry which is patently false.

Thus, "Each marriage can be considered a two person firm with either member the 'entrepreneur' who hires the other at ... salary and receives residual "profits'" (Becker, 1974: $302)$. With that symmetry of power and decision making assumed between the two parties and the theory of comparative advantage to explain the division of labour inside and outside the household, heterosexual marriage appears a perfect choice.

By implicitly generalising from married women to all women, the existence and the needs of women who are not attached to men are denied, and the norm of women's economic dependence is ideologically reinforced by both new (Mincer, Polachek) or old neoclassical economists (Marshall, Pigou, Edgeworth). One has to look hard to find references to single women, or to nolonger married women, let alone to lesbians - whom economists must never have heard of (Pujol, 1993: 9).

Feminist economists have deconstructed the status quo oriented/circular arguments of orthodoxy and the errors of the public private split, in which the market is primarily the site of male, selfish, individual, competitive and independent behaviour and the household centres on the female, with altruism and collective, cooperative, interdepend- 
ence prevalent. They have critiqued the assumptions of common household utility functions which ignore the reality of greater male power in most families, the complexities of cooperation and conflict, and the resulting adverse effects on many women (Ferber and Nelson, 1993; Hyman, 1994). Models of gender divisions of labour which perpetuate economic dependence for many women have been exposed and the supposed value freedom and objectivity of the model building questioned. However, most of this feminist writing has attempted to improve analysis and policy within the context of nuclear, sole parent, or extended families, with heterosexuality assumed, unstated, as the norm or only pattern.

Noting that early new home economics models of marriage were based on the metaphor of free trade between producers, and later, transaction costs based ones on the merger of independent firms, Elaine McCrate (1987) proposes a third metaphor, based on the hierarchical employment relation in the Marxian theory of the firm. This brings together feminist and Marxist writing on the family, in which unequal gender power relations are critical. She points out that the merger analogy, if to a slightly lesser extent than that of trade, falls short of acknowledging the systematic bias towards men having more power in marriage. "Capitalist ownership of the means of production and men's privileged access to the means of subsistence confer enormous power over workers and women... Men's power, much like capitalists' enables them to extract economic benefits from the dependent group" (McCrate, 1987: 79). Thus McCrate attributes high marriage rates to lack of alternatives until capitalist expansion of labour demand provided opportunities for women's economic independence. She shows the correlation between the declining proportion of women in marriages over a thirty year period, with greater exit and lesser entry, and an increasing measure of economic independence for women, calculated as a ratio of expected income inside and outside marriage.

Feminist analysis argues that a combination of self interest and the interests of others prevails in both public and private worlds, so attempting to break down the separation and addressing its adverse consequences for many women. This separation, with altruism assumed to be the main driving force in the female dominated private domain and self interest in the male dominated public domain, has underpinned much economic writing, old and recent (Pujol, 1992).

Feminist economic approaches, however diverse, are all suspicious of any rhetoric that describes women as less self-interested than men or automatically places gender interests on a lower level of analysis than family interest or class interest... Much contemporary feminist research focuses on the causes and consequences of unequal power between men and women (Folbre and Hartmann, 1988: 193).

Where lesbians and gay men are concerned, the defini- tions/meaning of family and couple relationships will be largely self constructed. Issues arise about how like/unlike heterosexual couple relationships they are, and how like/ unlike our communities want them to be in terms of treatment by society in general. Many lesbians believe that our relationships are different from - and have the potential to be better than - heterosexual ones, particularly in terms of relative power and working through its dynamics. The prevalence of children is probably lower than in heterosexual households, even though many lesbians are bringing up children from previous relationships and others are choosing to have children within lesbian community, often by artificial insemination.

Lesbians like myself, for whom identification as such is an important political statement as well as a personal fact or choice may wish to stress such differences. Analysis of the social construction of heterosexuality and gender, and family structures based on them, discussed earlier, is relevant here. The strategy of stressing how like heterosexuals we are, often allied in campaigns for equality to the view that sexual orientation is a genetic feature neither chosen nor able to be changed, will be unappealing to those with such perspectives. For some lesbians, however, expressing commitment to a partner and having this acknowledged and celebrated at least by close friends, for example through a ceremony, is of importance.

In pragmatic terms, many would argue that our partner relationships should be treated as favourably as those of heterosexual couples in terms of equal rights and nondiscrimination, legally and socially. At present there are cases of discrimination in judicial and policy judgements in areas such as adoption and custody of children, insemination services, domestic protection, partner benefits at work, superannuation benefits, honouring of wills, and next of kin treatment by the medical system. In the United States, medical costs are high, private provision the normal mode with only a minimal public system, and insurance coverage paid for by the employer fairly prevalent. Hence the availability of partner benefits for lesbians and gay men has been a major campaign by the community. Changes in New Zealand's health services will increase its importance here.

\section{Responsibility for raising children}

It was argued earlier that a blend of independence/self interest and interdependence/concern for the interests of others operates in all spheres. Some degree of interdependence and sharing of resources within and between various levels, including nuclear and extended families, communities and the state is inevitable and desirable. However, interdependence is more acceptable if it occurs by near consensus (the welfare state in the past is an example) or voluntarily than if it reduces to forced dependence on a spouse or the state. This perspective can be seen as requiring joint responsibility rippling outwards from individuals to the whole community in a variety of areas, particularly the upbringing of the next generation. Hence the 1988 
report of the Royal Commission on Social Policy saw a role for tax based support of children, including maintenance of a universal element. Their rationale included the recognition of a community responsibility for children, of the valuable caring work involved, and of the costs of raising children, to which society in general and those without children in particular, should contribute. If only a minority could afford to have children, the community would shrink and become unbalanced. In addition, the universal family benefit was an independent source of income for women and for some valued highly as their only such source. While its level, at \$6 per week universal child benefit, was only token, it demise in 1990 was a significant loss.

Motivated by the move to smaller government and a return to the rhetoric of self reliance, current directions imply a swing back to individual and family responsibility, and a reduced partnership with the community. Other policy elements are portrayed as helping the partnership, but are largely intended to be cost saving and behaviour changing. For example, the parents as first teachers programme is aimed at ensuring that parents will perform adequately. The revamped child support scheme, currently under review, is geared mainly at fiscal savings rather than better support for the custodial parent.

Targeted family support to low income earners and beneficiaries is not particularly generous, so that even for these groups community responsibility is limited. The level was not increased from its introduction in October 1986 until October 1993, when the ongoing rate of $\$ 42$ for the first child was supplemented by a rate of $\$ 35$ for additional children over thirteen and $\$ 24$ for those under thirteen. While involving an increase for second and later children under sixteen, the change is in fact a decrease of $\$ 7$ per week for second children over sixteen. Family support has been available in full since 1990/1 where family income was less than $\$ 17,500$, with abatement at 18 cents in the dollar up to $\$ 27,000$ and then at 30 cents. Family assistance is one area where levels are higher in Australia than New Zealand, and they are also price indexed there. In both countries direct payments to the mother are seen by women as crucial for ensuring a degree of intra-family equity and independence.

A reasonable feminist perspective is that partnered women should not be pushed out of the paid labour force nor unpartnered women with dependents pushed in, but that instead there should be real choice for each group, with minimal constraints. However, realism dictates that economic independence requires earnings from paid work. As a result of this, it can be argued that encouraging the option of full time parenting is not in women's interests (Landau, 1992). This does not mean that women should be expected to carry the double burden of paid work, together with most of the unpaid work. Instead, incentives for more equal sharing of unpaid work in the household of two parent families are needed, supplemented by adequate provision and support for child care. The low level of community support in this area, compared with the situa- tion in most European countries, again puts emphasis on individual responsibility. While per child subsidies to approved child care centres increased during the 1980 s, the levels of fees which are still necessary are too high for families where both parents are in low paid employment. The other area of government support, a payment to parents using such child care for up to 30 hours per week, is sharply income targeted.

Landau's position recognises the actual or likely consequences for women of dropping out of the labour force for long periods. Reentry to quality employment becomes more difficult as time out of the labour force increases. In two parent families, women who choose to withdraw from the labour force may be taking insufficient account of the possibility of later widowhood or marriage breakup with similar possible consequences. The costs of having children in terms of foregone earnings, as well as direct costs, are very high (Beggs and Chapman, 1988 have figures for Australia).

However, abatement regimes on benefits and family support provide severe disincentives for some groups of women to remain in the labour force or returning to it. Combined with weak demand for labour, this has halted the long term trend to higher female labour force participation. The poverty trap problems posed by high effective marginal tax rates, low levels of exempt income, and rapid abatement have long been recognised. Solutions are not easy, since less rapid abatement would result in reduced benefits still being paid at levels of income comparable with those of many in full time low paid work. This is often seen as politically unacceptable.

Tax systems and related policies have a significant effect on women's labour market participation. In Sweden women contribute $29 \%$ of family income, against $15 \%$ in Germany and $12 \%$ in the Netherlands. These differences relate closely to respective female labour force participation rates of those with children of six and under of $81 \%$, $54 \%$ and $50 \%$. Sweden has individual taxation and child care/parental leave/family support policies more supportive to dual eamer families, together with high marginal tax rates for single eamers, compared with the other two countries (Gustafsson and Bruyn-Hundt, 1991) and except for individual tax, compared to New Zealand.

\section{Equity within families - links to gender issues in the labour market}

British evidence suggests that only a small minority of couples had equal access to resources and their management. This was more likely to occur when wives earned as much or almost as much of the household income as their husbands (Vogler and Pahl, 1993). However, most attempts to measure impacts of policies on different groups by family type or income simply assume that observed household income is an adequate indicator of the welfare of the household, ignoring both intra-family distribution issues and non-market household production. 
Recent research in New Zealand covering one or both partners in 59 Pakeha couples with children, 20 Maori and 32 Pacific Island case studies, has yielded some fascinating insights into money control and management and ethnic differences in practice and attitudes (Easting and Fleming, 1994). Research teams from the different ethnic groups found that money was less a central source of satisfaction and self esteem among Pacific Island and Maori families, with its control a job to be done rather a source of power, and with greater priority given to extended family, whanau and community needs. Within Pakeha families, the British results were more closely replicated, with women's ability to control money and spend on themselves related to the proportion of the household income they directly earned.

More equal sharing of resources and both paid and unpaid work within couples is made difficult by women's lower average eaming power. On this issue, the Minister of Women's Affairs has claimed that the Employment Contracts Act "has done more towards providing equity for working women than any other development for a long time" (Evening Post, 1 December 1992). Others disagree! Raymond Harbridge's contract database shows a higher weighted average increase for men $(0.37 \%)$ compared with women $(0.14 \%)$ in the first eighteen months of the Act's operation and a lower overall rate of growth in earnings than the Quarterly Employment Survey used by the Minister in support of her arguments. He has convincingly explained why his figures, comparing the same group over time, are a truer reflection of reality (Harbridge, 1993a). Further, women were less likely to have contracts which attracted overtime or penal rates for inconvenient working hours or weekend days. Only in an area less directly related to take home pay, that of leave, were female dominated contracts slightly better than men's, with more providing a fourth week of annual leave and/or better than minimum sick leave (Hammond and Harbridge, 1993).

More generally, the claim that a deregulated labour market benefits women needs critical scrutiny (Novitz and Jaber, 1990). Certainly in terms of numbers employed and unemployed, women have done slightly less badly than men over the recent period of substantial job loss. However, this is largely because of women's overrepresentation in part time, casualised and low wage sections of the labour market, and in service industries/occupations which are under less employment pressures. The impact of deregulation on the wages and conditions of those in the casualised secondary sector is strongly negative (Harbridge, 1993a; Sayers, 1991). The labour market flexibility enhancement purpose of the ECA has been claimed by government ministers and the Business Roundtable among others potentially to advantage employees in general, and women in particular. However, such flexibility is mainly at the behest of and for the benefit of employers. Only the small proportion of women in highly scarce occupations can bargain flexibility gains of their own.

The negative impact of the Act on some low paid women is demonstrated in a 1993 survey of 962 women members of the Service Workers Union. This found that $40 \%$ had suffered a household income decline in the previous two years (Harbridge, 1993b): 30\% had lower take home pay, $47 \%$ the same, and only $20 \%$ higher than two years earlier, with a large part of this small increase coming from the longer hours reported by $15 \%$ of respondents. With as many as $32 \%$ reporting higher basic pay than before, the lower incidence of higher take home pay was largely due to abolition or reduction of overtime, penal, unsocial hours or weekend rates.

Equal pay for work of equal value, the principle underlying the pay equity part of the short lived Employment Equity Act, no longer has any legal underpinning. The apparently simpler equal pay for identical work was never as simple as it might seem. It becomes even more elusive in a highly deregulated labour market with inter firm and regional differences for otherwise the same work, and with individualised and performance based pay increasingly prevalent. In this climate the gender earnings gap may widen again and discrimination increase. While more women are progressing up vertical hierarchies, differentials generally are widening. Women and Maori are over-represented among employees defined as unskilled, the relative losers in this situation. Concepts and definations of skill are themselves largely a social construct. An effective minimum wage could be some protection for the lower paid, in which women predominate, but it has been unchanged for four years.

For the growing proportion of workers who are part-time, casualised, and/or homeworkers, in which women are overrepresented, minimum conditions may be even more crucial than it is for fulltime employees, although for such groups it is even harder to enforce any legislative requirements. The contracting out of large areas of work has eroded the distinction between employee and self employed. Only employees, on contracts of service, are covered by most labour legislation. Those on contracts for service have no such protections, so there is an incentive for employers to transfer work to this group. The coincidence of these trends is eroding the simple picture of a labour force with one person, one job, and instead producing a kaleidoscope where individuals may need several sources of work to survive, moving in and out of a number of them in a comparatively short time. The picture of the labour force produced by surveys based on old definitions is therefore becoming increasingly misleading.

Equal opportunity policies, too, have no legal underpinning outside the state sector since the repeal of the Employment Equity Act, although some enlightened firms understand both the equity and efficiency arguments for their implementation. The teamwork approach of workplace reform suggests a reduction in the numbers of levels and salary differentials between them. Glass ceilings currently often prevent women reaching the top positions in management, but also many women see the management process as needing radical change. The post Fordist organisation of work can reduce hierarchies, encourage the 
use of individual initiative by all employees, and support teamwork. Such workplace reform is thus congenial to many women, Maori and Pacific Islanders, and potentially reduces barriers to their progress. However, it provides both potential for equity policies to be taken seriously and dangers that women and others often marginalised in the workplace will be even more disadvantaged. Hopefully, efficiency motivations for productive use of all the human resource potential available may drive equal opportunity and family friendly policies within the context of an impending decline in numbers entering the labour force.

The Nissan agreement is an interesting case study of workplace reform. A study five years on shows that the shop floor workers generally feel positive about the changes (Ryan, 1993). The new management style and emphasis on teamwork was removing barriers and thus making it easier for women, Maori and Pacific Island employees to take on supervisory positions. Of the 108 employees, $28 \%$ were female, but women made up $48 \%$ of team leaders and $33 \%$ of forepersons and supervisors. The absence of vertical segregation with women mainly at the bottom was attributed by the women themselves "to the fact that they utilised many of the skills which they had developed in the domestic sphere - organising groups of people, coping with competing demands, coaching people in needed skills, and facilitating group decision-making" (ibid,p22). Ryan goes so far as to say that "the operation of teamwork has been largely congruent with the cultural values and assumptions of a largely Maori and Pacific Island workforce, and has resulted in an adaptation of 'Japanese' working practices as distinctively 'Pacific' ones", with Tilly Reedy calling the work organisation 'the Maori way' (ibid, p 27 and 29).

Self employment is another area of growth where women are underrepresented but increasing their presence rapidly. With many small businesses being only of short duration and the current growth propelled partly by the shortage of employment opportunities, it is not the solution for all or most of those seeking financially rewarding work. However it is an empowering option for many, and one in which women may be able to implement feminist principles.

Family friendly workplaces should involve improved domestic and (preferably, partly paid) parental leave, as well as a major boost to childcare funding and facilities. This could permit paid and unpaid work to be combined more easily, by men as well as women, thus reducing the double burden effect on women.

Many of the measures and areas discussed could benefit most men, as well as women. Many men are seeking to drop out of the management rat-race, and find trends towards greater teamwork and sharing of responsibility appealing. The situation of over employment in terms of time involvement for some, dependent on unpaid work by other members of their families, and unemployment or under employment for many others is absurdly unbalanced. Overemployment is partly a phenomenon of those high in hierarchies, but it may also be needed to make ends meet for people on low pay with a number of dependants.
For the latter group, higher basic pay and/or state support is needed. For the former group, 'family friendly' workplaces would attack overemployment as unnecessary, undesirable, unfair to dependants and partners, and discriminatory against those groups unable or unwilling to avoid unpaid caring commitments.

\section{Domestic violence}

When considering the ability for women to lead satisfying and happy lives, Marilyn Waring has pointed out that other elements are as crucial as economic concerns. Most models of the state, whether maximal or minimal, ignore sexism, racism and ageism, New Zealand conditions and power considerations.

When Nozick argues that the only legitimate forced extraction of income from citizens through taxation is for protective purposes, he did not have in mind protection from hunger or homelessness, nor did he have in mind making sexual harassment a criminal offence or introducing compulsory self defence classes for girls throughout our secondary schools ... It is clear that this model of the state is a description of liberties available for individual men inside the patriarchal power process. (Waring, 1988: 6-7).

Instead, Waring's conception of the state involves rights to services and 'survival rights,' individual entitlements and a respect for differences. This involves freedom 'from and to' many things, not just freedom from interference and to choose. A man's freedom from interference may mean a woman cannot walk safely in the streets.

The residue of the framework that women are owned by men, especially their husbands, continues to have major influence on the lives of many women and children. Expectations of sexual ownership and asymmetric standards of behaviour still prevail, reinforced by legal interpretation. For example, rape in marriage has only recently become illegal, and alleged provocation by women of male violence is given an amazingly wide latitude by male judges as an excuse, even for murder (McDonald, 1993). Recent cases show that the 'battered women's syndrome' of long term provocation through violence and control is not accorded the same sympathy in the rare cases of female retaliation. Male violence, and the threat of it, exerts considerable constraints on many women's freedom. Discussion which simply labels as unfortunate the increasing rate of marriage breakdown and advocates attempts to work at improving and continuing relationships ignores gender specific reasons for breakdown. Similar attitudes are often exhibited by police and judges (Busch et al, 1992 ). While police policy towards action on such violence has much improved, there is a long way to go in both prevention and protection.

\section{Conclusion}

Technological and social changes have provided a degree of economic independence for many women and improved opportunities to choose from a wider range of paid 
work. However, current government philososophy and policies threaten some of these gains, with many women facing severe constraints in making life choices. The year of the family appears to have offered little in improving this situation.

Possible directions of change include genuine societal valuation, not necessarily in monetary form, of all worthwhile activity. This includes household, voluntary and caring work, art, craft, sharing skills, and community activities, as well as paid work. Encouraging and valuing all worthwhile activity involves greatly reduced dichotomies between paid and unpaid work in terms of status, identity and entitlements. It can be assisted by a basic income scheme, which involves universal adult entitlement to a minimum living amount. Instead of being entitled to income support through belonging to a particular, usually disadvantaged category, such as being unemployed, sick or disabled, all adults would be entitled to such a basic income. This could reduce stigmatisation and feelings of reduced self-worth and morale experienced by many people currently dependent on benefits, effects which have exacerbated social problems including violence.

A basic income scheme, clawed back through the tax system for those on higher incomes, allows simplicity, adequacy, including augmentation of low earnings, and removal of the conception of the deserving and undeserving poor. New Zealand advocates of such schemes have preliminary calculations suggesting their viability (Rankin, 1991; Aotearoa Network of Unemployed and Beneficiaries, 1994). Combined with a climate of encouragement for skills acquisition, it could sharply reduce the hopelessness and destroyed self esteem of those currently unemployed and labelled as such, with the associated personal and social costs. Support for childcare would be needed to supplement the basic income. Policies on these lines could help in the quest for a less divided, more decent society for both women and men.

\section{Future research}

Basic information on standards of living, poverty lines and gaps, inter and intra household distribution of resources is still inadequate despite useful recent research by Berl/ Family Centre and Bob Stephens (Sunday Forum, 1991; Stephens, 1994). Assessment of both relative and absolute poverty is based on limited data, and needs both more research and more public discussion, with a view to policy options for income maintenance including a universal basic income. When Treasury can say of its calculations of total household income/expenditure needed for adequacy: "The budget for food can be multiplied by a factor to assess total household expenditure needs. In this case the food budget is multiplied by four. Some sources consider it adequate to multiply food needs by three and others consider five is a more fair figure" (New Zealand Treasury, 1990: 150), there is clearly a need for more work to assess what groups are 'missing out' and by how much. Differential gender measures and policy impacts, and parallel work on other structural variables, need better data and more work - both ethnographic (expanding/building on the work of Easting and Fleming) and statistical. Similarly, better ethnic and gender data on labour market outcomes and their analysis is needed.

Work is also needed on more complete indicators of economic welfare, as a guide to policy, than current national income statistics. This should include both varied social indicators and the construction of a single index for New Zealand more comprehensive than Gross National/ Domestic Product. For example, the Index of Sustainable Economic Welfare modifies personal consumption for distributional inequality, adds in the services of houshold labour, consumer durables, and streets and highways, and includes public consumption expenditure on health and education (Daly and Cobb, 1989). It also subtracts costs of pollution, depletion of non-renewable resources, commuting, urbanisation, and advertising, focussing on activity clearly contributing to human welfare.

\section{References}

Aotearoa Network of Unemployed and Beneficiaries, 1994 Employment: issues and solutions Auckland Unemployed Workers' Rights Centre

Arp, C.S., Arp D.H. and Mace, V. 1994 Today's families at risk Newsletter of the Aotearoa/New Zealand International Year of the Family May/June 2

Becker, G. 1974 A theory of marriage in T. W. Schultz (ed.) Economics of the family: marriage, children and human capital University of Chicago Press, Chicago 299-344

Beggs, J.J. and Chapman, B.J. 1988 The foregone earnings from child-rearing in Australia Australian National University Centre for Economic Policy Research Discussion Paper 190

Busch, R., Lapsley, H. and Robertson, N. 1992 Domestic violence and the justice system: a study of breaches of protection orders Report to Victims Task Force of New Zealand Department of Justice

Daly, H. E. and Cobb, J. B. Jr. 1989 For the common good - redirecting the economy towards community, the environment and a sustainable future Beacon Press, Boston

Dann, C. and Du Plessis, R. 1991 After the cuts: surviving on the Domestic Purposes Benefit University of Canterbury Department of Sociology Working Paper 12

Du Plessiz Novitz, R. 1990 Barriers and role choices: a response to "A longitudinal study of maternal participation in the full-time workforce parts 1 \& 2', M. Lloyd, D.M. Fergusson and L.J. Horwood New Zealand Population Review $15 / 2$ and 16/1 New Zealand Population Review 16(2): 57-62 
Easting, S.K. and Fleming R. 1994 Families, money and policy: summary of the intra family income study, and discussion of policy issues. Intra Family Income Project, Wellington

Ferber, M. A. and Nelson, J. A. (eds) 1993 Beyond economic man - feminist theory and economics University of Chicago Press, Chicago

Folbre, N. and Hartmann, H. 1988 The rhetoric of selfinterest: ideology and gender in economic theory' in A. Klamer, D. N. McCloskey and R. M. Solow (eds) The consequences of economic rhetoric Cambridge University Press, Cambridge/New York 184203

Gresham, Hon. P. 1994 Back us for International Year of the Family Start-up Kit New Zealand International Year of the Family

Gustafsson, S. and Bruyn-Hundt, M. 1991 Incentives for women to work: a comparison between The Netherlands, Sweden and West Germany Journal of Economic Studies 18 (5/6): 30-55

Hammond, S. and Harbridge, R. 1993 The impact of the Employment Contracts Act on women at work New Zealand Journal of Industrial Relations 18(1): 1530

Harbridge, R. 1993a The Employment Contracts Act: an assessment of the impact of the legislation on bargaining arrangements, paper presented to AIRAANZ Conference, Auckland

Harbridge, R. 1993b Service Workers Union women members survey Report to SWU

Hyman, P. 1994 Women and economics: a New Zealand feminist perspective Bridget Williams Books, Wellington

Landau, R. 1992 On making "choices" Feminist Issues 12: $47-72$

Mannion, R. 1993 Breaking up is hard to do Sunday Times 25 July: 21

Martin, Y. 1994 Why children need both their parents Sunday Star Times August 7: C1-2

McCrate, E. 1987 Trade, merger and employment: economic theory on marriage Review of Radical Political Economy 19(1): 73-89

McDonald, E. 1993 Provocation, sexuality and the actions of 'thoroughly decent' men Women's Studies Journal 9(2): 126-147

New Zealand Department of Social Welfare 1993 A profile of sole parents from the 1991 Census NZDSW, Wellington:
New Zealand Treasury 1990 Briefing to the incoming government NZ Treasury, Wellington

Novitz, R. du Plessiz and Jaber, N. 1990 Pay equity, the "free" market and state intervention New Zealand Journal of Industrial Relations 15(3): 251-262

Preston, D. 1993 The 1990/91 benefit changes, Unpublished paper delivered to Victoria University of Wellington seminar.

Pujol, M. A. 1993 Feminism, anti-feminism and early neo-classical economics, Paper to International Conference Out of the Margin: Feminist Perspectives on Economic Theory Amsterdam

Rankin, K. 1991 The universal welfare state incorporating proposals for a universal basic income University of Auckland Department of Economics Discussion Paper 12

Ryan, R. 1993 Japanisation: or a "New Zealand way"? Five years on at Nissan New Zealand Victoria University of Wellington Industrial Relations Centre Working Paper 5/93

Sayers, J. 1991 Women, the Employment Contracts Act and bargaining: a discussion paper New Zealand Journal of Industrial Relations 16(2): 159-166

Smith, S. 1994 Social order moulds unstable family units Campus Review Oct 27-Nov 2: 7

Stephens, R. 1987 Social welfare in Australia: a view from the east University of Melbourne Department of Economics Research Paper 169

Stephens, R. 1994 The incidence and severity of poverty in New Zealand, 1990-1991 Victoria University of Wellington Graduate School of Business and Govemment Management Working Paper 12/94

Sunday Forum 1991 prepared by the Family Centre and Business and Economic Research Limited. The National Government Budgets of the first year in office: a social assessment Wellington: New Zealand Educational Institute.

Vogler, C. and Pahl, J. 1993 Social and economic change and the organisation of money within marriage Work, Employment and Society 7(1): 71-95

Waring, M. 1988 Discussion paper on the role of the state in The role of the state: five perspectives Royal Commission on Social Policy, Wellington

\section{Author}

Prue Hyman is Associate Professor of Economics of Victoria University of Wellington, PO Box 600 , Wellington. 